\title{
Effect of Textile Sludge Application on Soil Microbial Properties
}

\author{
K. Anand Kumar, P. Prabhu Prasadini", R. Lakshmipathi, \\ N. Trimurthulu and G. Ramachandra Rao
}

\author{
Department of Environmental Sciences, Advanced Post Graduate Centre, ANGRAU, \\ Lam, Guntur - 522 034, Andhra Pradesh, India \\ *Corresponding author
}

\begin{tabular}{|c|c|}
\hline & \multirow{4}{*}{$\begin{array}{l}\text { A B S T R A C T } \\
\text { A study on "Effect of textile sludge application on soil microbial properties" was } \\
\text { conducted at Department of Environmental Sciences, Advanced Post Graduate Centre } \\
\text { Guntur during 2016-17 with sludge obtained from NSL Textiles Limited, Guntur District } \\
\text { Andhra Pradesh using fine textured soil from RARS, Lam. It was laid out in completely } \\
\text { randomized design with three replications often treatments comprising of three levels of } \\
\text { textile sludge }\left(3,5 \text { and } 10 \mathrm{tha}^{-1}\right) \text { each with three types viz., untreated sludge, sludge along } \\
\text { with microbial consortium and sludge decomposed with microbial consortium apart from } \\
\text { the control i.e., soil alone. Four such sets were maintained to facilitate destructive } \\
\text { sampling for estimation of soil microbial properties at initial, } 15,30 \text { and } 45 \text { days of } \\
\text { incubation. The results revealed that soil fungal and bacterial populations were found to } \\
\text { increase from initial to } 15 \text { days of incubation and decreased thereafter, from } 15 \text { days to } 45 \\
\text { days, gradually; whereas the populations increased with increasing doses of sludge. }\end{array}$} \\
\hline & \\
\hline Article Info & \\
\hline & \\
\hline
\end{tabular}

\section{Introduction}

Textile industry, the second largest sector in India after sugar industry, is facing problems regarding sludge disposal. Textile industry uses coagulants and chemicals to treat the effluent, leading to the generation of large amount of sludge from primary and secondary clarifiers. The sludge collected from clarifiers is dried in sludge drying beds and ultimately sent to landfills because of its chemical nature and less biological content.

There are reports pertaining to influence of sludge on microbiological aspects when it is applied to soil. Individual parameters such as microbial biomass and basic respiration or even enzyme activities have been widely used to measure the effects of different types of soil management practices on the soil microbiota (Schloter et al., 2003; Debosz et $a l ., 2002)$, including areas where sludge was applied (Armenta et al., 2012; Revoredo and Melo, 2007). Decrease in the microbial biomass and enzyme activities were observed in some studies due to the application of sewage sludge to the soil (Knight et al., 1997 and Kao et al., 2006), whereas in some soils, amendment with sewage sludge resulted in increased soil microbial activity, soil respiration and enzyme activities (Sastre et al., 1996 and Banerjee et al., 1997) clearly showing its enormous impacts on soil microbial activity. Hence, the present study 
was undertaken to elucidate the effect of textile sludge on soil microbial properties.

\section{Materials and Methods}

Incubation studies were carried out to know the effect of textile sludge on soil microbial properties. Textile sludge obtained from NSL Textiles Limited, Guntur and fine textured soil was collected from the top $15 \mathrm{~cm}$ in Lam Farm. Microbial consortia collected from A.R.S, Amravati comprised of Pseudomonas spp., Actinomycetes spp., Bacillus spp., Streptomyces spp. and Staphylococcus spp. Air dried soil $(<2 \mathrm{~mm}$ dia) with $\mathrm{pH}$ of 8.4 weighing $500 \mathrm{~g}$ was taken in plastic boxes and incubated at maximum water holding capacity for a period of 45 days, after imposing treatments. The treatments viz., control i.e., soil alone $\left(\mathrm{T}_{1}\right)$, Soil + sludge @ $3 \mathrm{t} \mathrm{ha}^{-1}\left(\mathrm{~T}_{2}\right)$, Soil + sludge@ $5 \mathrm{t} \mathrm{ha}^{-1}\left(\mathrm{~T}_{3}\right)$, Soil + sludge @10 t ha ${ }^{-1}\left(\mathrm{~T}_{4}\right)$, Soil + sludge @ $3 \mathrm{t} \mathrm{ha}^{-1}+$ microbial consortium $\left(\mathrm{T}_{5}\right)$, Soil + sludge @ 5 $\mathrm{t} \mathrm{ha}^{-1}+$ microbial consortium $\left(\mathrm{T}_{6}\right)$, Soil + sludge @10 t ha ${ }^{-1}+$ microbial consortium $\left(\mathrm{T}_{7}\right)$, Soil + sludge decomposed for 15 days with microbial consortium @ $3 \mathrm{t} \mathrm{ha}^{-1}\left(\mathrm{~T}_{8}\right)$, Soil + sludge decomposed for 15 days with microbial consortium @ $5 \mathrm{t} \mathrm{ha}^{-1}\left(\mathrm{~T}_{9}\right)$ and Soil + sludge decomposed for 15 days with microbial consortium @ $10 \mathrm{t} \mathrm{ha}^{-1}\left(\mathrm{~T}_{10}\right)$ were laid in CRD with three replications. Four such sets were maintained to facilitate destructive sampling for estimation of soil microbial properties at initial, 15, 30 and 45 days of incubation.

\section{Enumeration of microbial load}

The enumeration of total fungi and bacteria in the soil samples was carried out by following the standard dilution plate count technique. The procedure includes, ten grams of soil from each treatment was taken in a conical flask to which $100 \mathrm{~mL}$ of sterile saline was added aseptically. The sample was agitated for 15 minutes on an orbital shaker and serial dilutions of soil suspensions were prepared. An aliquot of $0.1 \mathrm{~mL}$ of respective dilutions were spread on the surface of sterile agar medium (Nutrient agar for bacteria, Potato dextrose agar for fungi) contained in sterile Petri plates. Then the Petri plates were incubated at room temperatures $\left(28^{0} \mathrm{C} \pm 2^{0} \mathrm{C}\right)$ for 24-72 in a bacteriological incubator. After incubation colonies formed were counted using digital colony counter. Fungi count was taken after 24h; while bacteria count was taken after $72 \mathrm{~h}$ and the population was expressed as CFU $\mathrm{x}$ dilution factor per gram (Aneja, 2001).

\section{Results and Discussion}

\section{Fungal population}

The fungal populations in different sludge treatments recorded over 45 days of incubation of soil are presented in CFU per gram of soil along with their log values in Table 1.

The fungal population was found to increase from initial to 15 days and thereafter, decreased from 15 days to 45 days gradually. The increase was from $9.04 \times 10^{4}$ to $10.91 \times 10^{4}$ CFU g ${ }^{-1}$ and decrease was from $10.91 \times 10^{4}$ to $4.23 \times 10^{4} \mathrm{CFU} \mathrm{g}^{-1}$.

However, the fungal population was highest in the treatment $\mathrm{T}_{10}(13.73,13.60,10.66$ and $7.0 \times 10^{4} \mathrm{CFU} \mathrm{g}^{-1}$, respectively at initial, 15 , 30 and 45 days of incubation) and least in case of $\mathrm{T}_{1^{-}} \quad(2.06,4.66,5.00$ and $5.00 \times 10^{4} \mathrm{CFU} \mathrm{g} \mathrm{g}^{-1}$, respectively at initial, 15 , 30 and 45 days of incubation).In all treatments decomposed sludge applied treatments recorded highest values then treated and untreated sludge. The highest fungal population was recorded in $10 \mathrm{t} \mathrm{ha}^{-1}$ sludge applied treatments compared to 5 and $3 \mathrm{t} \mathrm{ha}^{-1}$ applied sludge. 
The data recorded in $\mathrm{CFU} \mathrm{g} \mathrm{g}^{-1}$ was converted to $\log _{4}$ value (Table 1) for statistical analysis. The analysis indicated that the sludge treatments and incubation intervals affected the fungal population significantly and their interaction was also found to be statistically significant.

Over all, the highest (5.21 $\log _{4}$ valueper gram) fungal population was recorded in the treatment $\mathrm{T}_{4}$ (Soil + sludge @ $10 \mathrm{t} \mathrm{ha}^{-1}$ ) at 15days of incubation and lowest (4.31 $\log _{4}$ valueper gram) was recorded in the treatment $\mathrm{T}_{1}$ (control) at initial.

Average values over 10 treatments, indicated that the fungal population was increased from initial to 15days and thereafter, decreased gradually. The increase was from 4.88 to 5.00 $\log _{4}$ valueper gram and decrease was from 5.00 to 4.85 (at 30days) and further to 4.59 (at 45days). Statistically, the variations were not significant except the decrease at 45 days interval. This might be due to release of inorganic nutrients by decomposition of organic matter and also depletion of nutrients over a period. Similar results were obtained by Tripathi and Devendra (2011) in their studies with distillery sludge.

In general, during decomposition of organic matter, the process will be peak around 30 days which will generate more heat this might have affected certain groups of microorganisms. Dumontet et al., (1999) also observed decrease in microbial population after peak stage of decomposition and they attributed this aspect to depletion of nutrients during decomposition over a period.

The average values over incubation intervals and sludge treatments, revealed that the highest (5.02 $\log _{4}$ value per gram) fungal population was recorded in $10 \mathrm{t} \mathrm{ha}^{-1}$ sludge applied treatments compared to 4.87 in $5 \mathrm{t} \mathrm{ha}$ ${ }^{1}$ sludge combinations and $4.67 \log _{9}$ value per gram in $3 \mathrm{t} \mathrm{ha}^{-1}$ sludge treatments. Fungal population was highest in sludge and microbial consortium combinations followed by sludge alone and least was recorded in control, which might be due to increased organic matter content on application of treated/decomposed sludge. In treated sludge the toxic metal concentration was reduced compared to untreated sludge (CETESB, 1999). Non-toxic effects of composted and untreated textile sludge on microbial population was also reported by McGrath et al., (1995) in their study with different forms of textile effluent sludge on microbial population.

\section{Bacterial population}

Bacterial population recorded in soil incubated with textile sludge alone and with decomposing cultures, in CFU per gram of soil and their log values are presented in Table 2.

The data showed that the bacterial population was highest in the treatment $\mathrm{T}_{10}(653,690$, 636 and $626 \times 10^{9} \mathrm{CFU} \mathrm{g}^{-1}$, respectively at initial, 15, 30 and 45 days of incubation) and least in case of $\mathrm{T}_{1}(213,323,276$ and 243 $\times 10^{9} \mathrm{CFU} \mathrm{g}^{-1}$ respectively at initial, 15,30 and 45 days of incubation). It increased from initial to 15 days (from 487.6 to $527.4 \times 10^{9}$ CFU $\mathrm{g}^{-1}$ ) of incubation and thereafter decreased to 45 days $\left(420.8 \times 10^{9} \mathrm{CFU} \mathrm{g} \mathrm{g}^{-1}\right)$ gradually. Over all, decomposed sludge applied treatments $\left(\mathrm{T}_{8}, \mathrm{~T}_{9}\right.$ and $\left.\mathrm{T}_{10}\right)$ recorded highest values followed by treated $\left(\mathrm{T}_{5}, \mathrm{~T}_{6}\right.$ and $\left.\mathrm{T}_{7}\right)$, untreated sludge $\left(\mathrm{T}_{2}, \mathrm{~T}_{3}\right.$ and $\left.\mathrm{T}_{4}\right)$ and the lowest by control $\left(\mathrm{T}_{1}\right)$. The highest bacterial population was recorded in $10 \mathrm{t} \mathrm{ha}^{-1}$ sludge applied treatments compared to 5 and $3 \mathrm{t} \mathrm{ha}^{-1}$ applied sludge. Average values over 45 days of incubation revealed that composted sludge recorded $10 \%$ more bacterial population compared to treated sludge and $21 \%$ compared to untreated sludge. 
Table.1 Effect of application of textile sludge alone and in combination with decomposing microbial consortium on soil fungal population during incubation

\begin{tabular}{|c|c|c|c|c|c|}
\hline \multirow{2}{*}{ Treatments } & \multicolumn{5}{|c|}{ Fungal population per gram $\left(\log _{4}\right.$ value) } \\
\hline & Initial* & 15days* & 30days* & 45days* & Mean \\
\hline \multirow[t]{2}{*}{$\mathrm{T}_{1}$ - Soil alone (control) } & 4.31 & 4.66 & 4.69 & 4.69 & 4.58 \\
\hline & $(2.06)$ & $(4.66)$ & $(5.00)$ & $(5.00)$ & $(4.18)$ \\
\hline \multirow[t]{2}{*}{$\mathrm{T}_{2}$ - Soil + sludge @ $3 \mathrm{tha}^{-1}$} & 4.66 & 4.86 & 4.69 & 4.22 & 4.60 \\
\hline & $(4.60)$ & $(7.33)$ & $(5.00)$ & $(1.66)$ & $(4.64)$ \\
\hline \multirow[t]{2}{*}{$\mathrm{T}_{3}-$ Soil + sludge @ $5 \mathrm{t} \mathrm{ha}^{-1}$} & 4.92 & 5.06 & 4.86 & 4.47 & 4.82 \\
\hline & $(8.40)$ & $(11.66)$ & $(7.33)$ & $(3.00)$ & $(7.59)$ \\
\hline \multirow[t]{2}{*}{$\mathrm{T}_{4}$ - Soil + sludge @10 tha ${ }^{-1}$} & 5.14 & 5.21 & 5.04 & 4.75 & 5.03 \\
\hline & $(13.96)$ & $(16.30)$ & $(11.00)$ & $(5.66)$ & $(11.73)$ \\
\hline \multirow{2}{*}{$\begin{array}{l}\mathrm{T}_{5}-\text { Soil }+ \text { sludge @ } 3 \mathrm{t} \mathrm{ha}^{-1}+ \\
\text { microbial consortium }\end{array}$} & 4.79 & 4.95 & 4.69 & 4.42 & 4.71 \\
\hline & (6.30) & $(9.00)$ & $(5.00)$ & $(2.66)$ & $(5.74)$ \\
\hline \multirow{2}{*}{$\begin{array}{llllll}\mathrm{T}_{6} & - \text { Soil +sludge@ } & 5 & \mathrm{t} & \mathrm{ha}^{-1}+ \\
\text { microbial consortium } & & & & & \\
\end{array}$} & 5.07 & 5.11 & 4.90 & 4.63 & 4.92 \\
\hline & $(11.83)$ & 13.00) & $(8.00)$ & $(4.33)$ & $(9.29)$ \\
\hline \multirow{2}{*}{$\begin{array}{l}\mathrm{T}_{7}-\text { Soil + sludge } @ 10 \mathrm{t} \mathrm{ha}^{-1}+ \\
\text { microbial consortium }\end{array}$} & 5.19 & 5.20 & 5.07 & 4.56 & 5.00 \\
\hline & $(15.50)$ & $(16.00)$ & $(12.00)$ & $(3.66)$ & $(11.79)$ \\
\hline \multirow{2}{*}{$\begin{array}{l}\mathrm{T}_{8} \text { - Soil + sludge decomposed with } \\
\text { microbial consortium @ } 3 \mathrm{tha}^{-1}\end{array}$} & 4.75 & 4.88 & 4.63 & 4.60 & 4.71 \\
\hline & $(5.73)$ & $(7.60)$ & $(4.33)$ & $(4.00)$ & $(5.41)$ \\
\hline \multirow{2}{*}{$\begin{array}{l}\mathrm{T}_{9} \text { - Soil + sludge decomposed with } \\
\text { microbial consortium @ } 5 \mathrm{tha}^{-1}\end{array}$} & 4.91 & 5.00 & 4.92 & 4.72 & 4.88 \\
\hline & $(8.30)$ & $(10.00)$ & $(8.33)$ & $(5.33)$ & (7.99) \\
\hline \multirow{2}{*}{$\begin{array}{l}\mathrm{T}_{10} \text { - Soil + sludge decomposed with } \\
\text { microbial consortium @ } 10 \mathrm{tha}^{-1}\end{array}$} & 5.13 & 5.13 & 5.02 & 4.84 & 5.03 \\
\hline & $(13.73)$ & (13.60) & (10.66) & $(7.00)$ & (11.24) \\
\hline \multirow[t]{2}{*}{ Mean } & 4.88 & 5.00 & 4.85 & 4.59 & \\
\hline & (9.04) & $(10.91)$ & (7.66) & $(4.23)$ & \\
\hline \multirow[t]{2}{*}{ Factors } & & B(incubation & & & \\
\hline & A(treatments) & periods) & $\mathbf{A} \times \mathbf{B}$ & & \\
\hline CD & 0.472 & 0.259 & 0.818 & & \\
\hline SE(m) & 0.167 & 0.092 & 0.289 & & \\
\hline
\end{tabular}

Note: Values in the parentheses $\left(\times 10^{4}\right)$ represent the original population without log conversion.

*Incubation Period 
Table.2 Effect of application of textile sludge alone and in combination with decomposing microbial consortium on soil bacterial population during incubation

\begin{tabular}{|c|c|c|c|c|c|}
\hline \multirow{2}{*}{ Treatments } & \multicolumn{5}{|c|}{ Bacterial population per gram (log9 value) } \\
\hline & Initial* & 15days* & 30days* & 45days* & Mean \\
\hline $\mathrm{T}_{1}-$ Soil alone (control) & $\begin{array}{l}11.32 \\
(213)\end{array}$ & $\begin{array}{l}11.50 \\
(323)\end{array}$ & $\begin{array}{l}11.44 \\
(276)\end{array}$ & $\begin{array}{l}11.38 \\
(243)\end{array}$ & $\begin{array}{c}11.41 \\
(264.5)\end{array}$ \\
\hline $\mathrm{T}_{2}$ - Soil + sludge @ $3 \mathrm{t} \mathrm{ha}^{-1}$ & $\begin{array}{l}11.53 \\
(343)\end{array}$ & $\begin{array}{l}11.59 \\
(390)\end{array}$ & $\begin{array}{l}11.55 \\
(360)\end{array}$ & $\begin{array}{l}11.46 \\
(293)\end{array}$ & $\begin{array}{c}11.53 \\
(346.5)\end{array}$ \\
\hline $\mathrm{T}_{3}$ - Soil + sludge @ $5 \mathrm{tha}^{-1}$ & $\begin{array}{l}11.58 \\
(386)\end{array}$ & $\begin{array}{l}11.62 \\
(420)\end{array}$ & $\begin{array}{l}11.58 \\
(386)\end{array}$ & $\begin{array}{l}11.51 \\
(330)\end{array}$ & $\begin{array}{c}11.57 \\
(380.5) \\
\end{array}$ \\
\hline $\mathrm{T}_{4}$ - Soil + sludge @10 t ha ${ }^{-1}$ & $\begin{array}{l}11.62 \\
(423)\end{array}$ & $\begin{array}{l}11.66 \\
(466)\end{array}$ & $\begin{array}{l}11.60 \\
(400)\end{array}$ & $\begin{array}{l}11.57 \\
(380)\end{array}$ & $\begin{array}{c}11.61 \\
(417.2)\end{array}$ \\
\hline $\begin{array}{l}\mathrm{T}_{5}-\text { Soil + sludge @ } 3 \mathrm{t} \mathrm{ha}^{-1}+ \\
\text { microbial consortium }\end{array}$ & $\begin{array}{l}11.68 \\
(480)\end{array}$ & $\begin{array}{l}11.71 \\
(513)\end{array}$ & $\begin{array}{l}11.62 \\
(420)\end{array}$ & $\begin{array}{l}11.59 \\
(393)\end{array}$ & $\begin{array}{l}11.65 \\
(451.5)\end{array}$ \\
\hline $\begin{array}{l}\mathrm{T}_{6}-\text { Soil +sludge@ } 5 \mathrm{t} \mathrm{ha}^{-1}+ \\
\text { microbial consortium }\end{array}$ & $\begin{array}{l}11.74 \\
(560)\end{array}$ & $\begin{array}{l}11.75 \\
(573)\end{array}$ & $\begin{array}{l}11.64 \\
(446)\end{array}$ & $\begin{array}{l}11.60 \\
(403)\end{array}$ & $\begin{array}{c}11.68 \\
(495.5)\end{array}$ \\
\hline $\begin{array}{l}\mathrm{T}_{7}-\text { Soil + sludge @ } 10 \mathrm{t} \mathrm{ha}^{-1}+ \\
\text { microbial consortium }\end{array}$ & $\begin{array}{l}11.76 \\
(586)\end{array}$ & $\begin{array}{l}11.78 \\
(613)\end{array}$ & $\begin{array}{l}11.71 \\
(513)\end{array}$ & 11.64 & $\begin{array}{c}11.72 \\
(538.0)\end{array}$ \\
\hline $\begin{array}{l}\mathrm{T}_{8} \text { - Soil + sludge decomposed with } \\
\text { microbial consortium @ } 3 \mathrm{t} \mathrm{ha}^{-1}\end{array}$ & $\begin{array}{l}11.78 \\
(606)\end{array}$ & $\begin{array}{l}11.80 \\
(636)\end{array}$ & $\begin{array}{l}11.76 \\
(583)\end{array}$ & $\begin{array}{l}11.72 \\
(530)\end{array}$ & $\begin{array}{c}11.76 \\
(588.7)\end{array}$ \\
\hline $\begin{array}{l}\mathrm{T}_{9} \text { - Soil + sludge decomposed with } \\
\text { microbial consortium @ } 5 \mathrm{t} \mathrm{ha}^{-1}\end{array}$ & $\begin{array}{l}11.79 \\
(626)\end{array}$ & $\begin{array}{l}11.81 \\
(650)\end{array}$ & $\begin{array}{l}11.78 \\
(603)\end{array}$ & $\begin{array}{l}11.75 \\
(570)\end{array}$ & $\begin{array}{c}11.78 \\
(612.2)\end{array}$ \\
\hline $\begin{array}{l}\mathrm{T}_{10} \text { - Soil + sludge decomposed with } \\
\text { microbial consortium @ } 10 \mathrm{tha}^{-1}\end{array}$ & $\begin{array}{l}11.81 \\
(653)\end{array}$ & $\begin{array}{l}11.83 \\
(690)\end{array}$ & $\begin{array}{l}11.80 \\
(636)\end{array}$ & $\begin{array}{l}11.79 \\
(626)\end{array}$ & $\begin{array}{l}11.80 \\
(651.2)\end{array}$ \\
\hline Mean & $\begin{array}{c}11.66 \\
(487.6) \\
\end{array}$ & $\begin{array}{c}11.70 \\
(527.4) \\
\end{array}$ & $\begin{array}{c}11.64 \\
(462.6) \\
\end{array}$ & $\begin{array}{c}11.60 \\
(420.8) \\
\end{array}$ & \\
\hline Factors & $\begin{array}{l}\text { A(treat } \\
\text { ments })\end{array}$ & $\begin{array}{l}\mathrm{B} \text { (incubati } \\
\text { on periods) }\end{array}$ & $\mathbf{A} \times \mathbf{B}$ & & \\
\hline CD & 0.089 & 0.049 & 0.154 & & \\
\hline SE(m) & 0.032 & 0.017 & 0.055 & & \\
\hline
\end{tabular}

Note: Values in the parentheses $\left(\times 10^{9}\right)$ represent the original population without log conversion.

*Incubation Period

The data recorded in CFU g ${ }^{-1}$ was converted to $\log _{9}$ value (Table 2 ) for statistical analysis. The analysis indicated that there was a significant variation in bacterial population among the treatments, among the incubation intervals and their interaction was also found significant.

Over sludge treatments, the mean bacterial population was found to increase from initial to 15 days of incubation and thereafter, decreased from 15 days to 45 days, gradually.
The increase was from 11.66 to $11.70 \log _{9}$ value per gram and was statistically not significant, but it decreased significantly at 30 and 45 days of incubation intervals compared to that recorded at 15 days. This might be due to release of inorganic nutrients by decomposition of organic matter and also depletion of nutrients over a period. Similar results were observed by Tripathi and Devendra (2011) in their experiment with distillery sludge. In general, during decomposition of organic matter, the process 
will be peak around 30 days which will generate more heat, this might have affected certain groups of microorganisms. Dumontet et al., (1999) also observed decrease in microbial population during peak stage of decomposition. They also attributed it to depletion of nutrients during decomposition over a period.

The average values over incubation intervals and sludge treatments, revealed that the highest (11.71 $\log _{9}$ value per gram) bacterial population was recorded in $10 \mathrm{t} \mathrm{ha}^{-1}$ sludge applied treatments compared to 5 (11.68 $\log _{9}$ value per gram) and $3 \mathrm{t} \mathrm{ha}^{-1}$ sludge (11.65 $\log _{9}$ value per gram). The average values over incubation and levels of sludge indicated that the bacterial population was highest (11.78 $\log _{9}$ per gram) with decomposed sludge ( $\mathrm{T}_{8}$ to $\mathrm{T}_{10}$ ) followed by treated sludge ( $\mathrm{T}_{6}$ to $\left.\mathrm{T}_{8}\right)$ as $11.68 \log _{9}$ per gram and sludge alone $\left(\mathrm{T}_{2}\right.$ to $\left.\mathrm{T}_{4}\right)$ as $11.57 \log _{9}$ per gram. Least was recorded in control as $11.41 \log _{9}$ per gram. Non-toxic effects of composted and untreated textile sludge on microbial population was reported by McGrath et al., (1995) in their study with different forms of textile effluent sludge on microbial population. In treated sludge the toxic metal concentration was reduced compared to untreated sludge (CETESB, 1999).

The bacterial population was highest in the treatment $\mathrm{T}_{10}(11.81,11.83,11.80$ and 11.79 $\log _{9}$ value per gram respectively at initial, 15, 30 and 45 days of inoculation) and least in case of $\mathrm{T}_{1}\left(11.32,11.50,11.44\right.$ and $11.38 \log _{9}$ value per gram respectively at initial, 15, 30 and 45 days of inoculation). Variation in bacterial population between the treatments might be attributed to changes in quality and quantity of sludge added to the soil. In this study, there were three types of sludge added to the soil, sludge in $T_{2}$ to $T_{4}$; treated sludge (sludge + decomposing microbial consortium) in $\mathrm{T}_{5}$ to $\mathrm{T}_{7}$; and decomposed sludge (sludge incubated with decomposing microbial consortium before application to soil) in $\mathrm{T}_{8}$ to $\mathrm{T}_{10}$; and this variation might be one of the reason for variation in bacterial population.

In this study the application of textile sludge, particularly with conjoint application of decomposing microbial consortium showed improvement in soil microbial properties and it can be interpreted that application of textile sludge would be helpful in maintaining the soil quality by increasing the microbial load in the soil viz., fungi and bacteria population which are essential for increasing nutrient availability to all crops provided the environmental concerns are duly addressed through composting of textile sludge by promising microbial consortia to keep the toxic heavy metal contents under permissible limits.

\section{References}

Aneja, K.R. 2001. Experiments in microbiology, plant pathology and tissue culture. Viswaprakasham. New Delhi. 471 Pp.

Armenta, R., Vaca, R., Lugo, J and Aguiladel, P. 2012. Microbial and biochemical properties of an agricultural Mexican soil amended with sewage sludge. RevBrasCiênc Solo. 36: 1646-1655.

Banerjee, M.R., Burton, D.L., Depoe, S. 1997. Impact of sewage sludge application on soil biological characteristics. Agric Ecosyst Environ. 66:241-249.

CETESB. 1999. Application of sludge of biological treatment systems in agricultural areas - criteria for project and operation Technical Manual of Company of Environmental Sanitation Technology. Pp. 1-32.

Debosz, K., Peterson, S.O., Kure, L.K and Ambus, P. 2002. Evaluating effects of sewage sludge and household compost 
on soil physical, chemical and microbiological properties. Appl Soil Ecol. 19: 237-248.

Dumontet, S., Dinel, H. and Baloda, S.B. 1999. Pathogen reduction in sewage sludge by composting and other biological treatments: A Review. Biological Agriculture and Horticulture. 16: 40-43.

Kao, P.H., Huang, C.C and Hseu, Z.Y. 2006. Response of microbial activities to heavy metals in a neutral loamy soil treated with biosolid. Chemosphere. 64: 63-70.

Knight, B.P., McGrath, S.P and Chaudri, A.M. 1997. Biomass carbon measurements and substrate utilization patterns of microbial populations from soils amended with cadmium, copper or zinc. Appl Environ Microbiol. 63: 3943.

McGrath, S.P., Chaudri, A.M and Giller, K.E. 1995. Long-term effects of metals in sewage sludge on soils, microorganisms and plants. Journal of Industrial Microbiology. 14: 94-104.

Revoredo, M.D and Melo, W.J. 2007. Enzyme activity and microbial biomass in an Oxisol amended with sewage sludge Contaminated with nickel. Scientia Agricola. 64: 61-67.

Sastre, I., Vicente, M.A and Lobo, M.C. 1996. Influence of the application of sewage sludges on soil microbial activity. Bioresour Technol. 57: 19-23.

Schloter, M., Dilly, O and Munch, J.C. 2003. Indicators for evaluating soil quality. Agric Ecosyst Environ. 98: 255-262.

Tripathi, B. D and Devendra, T.M. 2011. Toxic Effects of Distillery Sludge Amendment on Microbiological and Enzymatic Properties of Agricultural Soil in a Tropical City. Journal of Environment Analytic Toxicology. 1: 102.

\section{How to cite this article:}

Anand Kumar, K., P. Prabhu Prasadini, R. Lakshmipathi, N. Trimurthulu and Ramachandra Rao, G. 2017. Effect of Textile Sludge Application on Soil Microbial Properties. Int.J.Curr.Microbiol.App.Sci. 6(12): 2006-2012. doi: https://doi.org/10.20546/ijcmas.2017.612.230 